This article was downloaded by: [University of the West of England]

On: 28 September 2010

Access details: Access Details: [subscription number 917396293]

Publisher Routledge

Informa Ltd Registered in England and Wales Registered Number: 1072954 Registered office: Mortimer House, 3741 Mortimer Street, London W1T 3JH, UK

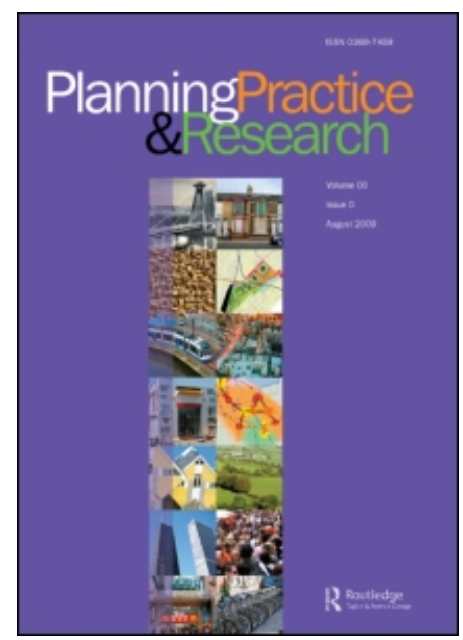

\title{
Planning Practice and Research
}

Publication details, including instructions for authors and subscription information:

http://www.informaworld.com/smpp/title content=t713442503

\section{An Investigation of the Nature of Vacant Commercial and Industrial Property}

Mutale Katyoka; Peter Wyatt

To cite this Article Katyoka, Mutale and Wyatt, Peter(2008) 'An Investigation of the Nature of Vacant Commercial and Industrial Property', Planning Practice and Research, 23: 1, 125 - 145

To link to this Article: DOI: 10.1080/02697450802076704

URL: http://dx.doi.org/10.1080/02697450802076704

\section{PLEASE SCROLL DOWN FOR ARTICLE}

Full terms and conditions of use: http://www.informaworld.com/terms-and-conditions-of-access.pdf

This article may be used for research, teaching and private study purposes. Any substantial or systematic reproduction, re-distribution, re-selling, loan or sub-licensing, systematic supply or distribution in any form to anyone is expressly forbidden.

The publisher does not give any warranty express or implied or make any representation that the contents will be complete or accurate or up to date. The accuracy of any instructions, formulae and drug doses should be independently verified with primary sources. The publisher shall not be liable for any loss, actions, claims, proceedings, demand or costs or damages whatsoever or howsoever caused arising directly or indirectly in connection with or arising out of the use of this material. 


\title{
An Investigation of the Nature of Vacant Commercial and Industrial Property
}

\author{
MUTALE KATYOKA \& PETER WYATT
}

\section{Introduction}

The UK Government publishes annual statistics relating to the number, size and value of commercial and industrial premises in England, and has done so since 1998 (Office of the Deputy Prime Minister [ODPM], 2006a). These statistics break down the non-domestic building stock into its principal land uses and geographical locations. There has been growing political interest in monitoring the amount of vacant non-domestic building stock and measuring the number, size and value of such premises both in absolute terms and also as a proportion of total stock. The interest arises because vacant property is a useful indicator of urban change and represents a resource that may require government intervention to encourage reuse. Nearly 20 years ago the Government confirmed that an 'up to date or even accurate figure of the national stock of vacant land is not available-whether presented on its own or in comparison with the stock of used land' (Department of the Environment, 1988). Recording the location and characteristics of vacant buildings was regarded as more problematic than doing so for vacant land and was only seriously considered when the re-use of brownfield (or, more accurately, previously developed land) became a central tenet of Government policy in the early part of this century (ODPM, 2005c).

Myers and Wyatt (2004) argued that it is important not only to consider vacant and derelict land but also vacancy within buildings. Indeed the National Land Use Database initiative requires local authorities in England to compile information about vacant land and buildings, but it is acknowledged that it is more difficult to identify vacancy (and partial vacancy) within buildings and even more difficult to record attributes such as floor area and condition. Myers and Wyatt (2004) described a way of combining information on vacant commercial and industrial premises collected by the Government for property taxation purposes with information on vacant premises collected by local authorities. The combined data set allows the compilation of statistics on commercial and industrial vacancy in England and Wales for local authorities wishing to supply data. This paper uses a sample of these data to examine the nature and location of vacant commercial and 
industrial property in a post-industrial city in the north of England. It is possible to determine the nature of vacant business premises (length of vacancy, size, age and type of premises) and locate them in order to identify clusters of long-term vacant property that may be suitable for regeneration.

The paper is structured as follows. The next section describes the way in which property tax records can be used as a source of information about vacant nondomestic premises. The third section describes the case-study method that was used in Leeds to collect and process information in preparation for the analysis described in the fourth section. The final section offers some concluding comments.

\section{Property Tax Records as a Source of Vacancy Information}

Non-domestic premises in England and Wales that are subject to property taxation or Business Rates are known as 'hereditaments'; literally, a legal interest in property that is capable of being inherited. Commercial and Industrial Floorspace and Rateable Value Statistics (ODPM, 2006a) report the number of hereditaments, total floorspace, total rateable value, and rateable value per square metre for each of the main land uses (retail, offices, factories and warehouses) for each local authority in England. The information comes from the administrative databases used by the Valuation Office Agency (VOA) to assess the rateable value of each hereditament in England and Wales (Bruhns et al., 2000). These assessments are undertaken every 5 years and involve government valuers collecting and analysing evidence of market rents in order to estimate the rateable value of each hereditament at a particular point in time. The latest set of assessments relate to market rents as they were on 1 April 2003 and the resultant (current) rating list was published on 1 April 2005. So the rateable value of a hereditament is based essentially on its rental value and this, in turn, is driven by a range of factors including the use, location and physical characteristics of the premises. A major determinant of rental value is often floorspace. Thus for many of the more common types of commercial premises, the VOA measures floor area as part of the detailed internal surveys of buildings that it undertakes to assess rateable values. The VOA assesses all properties regardless of whether they are occupied or vacant, although properties that are not capable of beneficial occupation, such as derelict buildings, are not rateable. The fact that a property is vacant has no impact on its rateable value, although it can affect the amount of business rates that are paid; this is explained in more detail below.

Hereditaments are classified by the VOA as either 'bulk' or 'non-bulk'. Bulk classes include the main land-use types (retail, offices, factories and warehouses). Hereditaments that are not in any one of the four bulk classes are collectively known as non-bulks and include hotels, public houses, schools, hospitals, libraries and premises used for leisure activity. Floorspace and other descriptive statistics are generally not available for non-bulk hereditaments (Bruhns, 2000). A very small minority of business premises are exempt from paying Business Rates altogether and hence are excluded from the statistics, including agricultural land and buildings and fish farms.

There are situations where business premises can be refunded part or all of the Business Rates they have paid. The amount they receive back is called relief, and 
vacant premises are amongst those that qualify for relief. The amount of relief that can be received depends on both the period of time for which a property has been vacant and the use to which the property is put. For the first 3 months that a property has been vacant it receives $100 \%$ relief regardless of its bulk class; after that, retail and office premises receive $50 \%$ relief while factories and warehouses still receive $100 \%$ relief from rates.

For the past 5 years the Government has published a vacancy statistic for each local authority by analysing the rateable values and the amount of relief granted to occupiers and owners of hereditaments each year (ODPM, 2005b). The statistic is derived from data that are collected annually from each local authority on the financial amount of relief given to businesses. However, because the primary purpose of these data is revenue calculation by the Treasury, only the total amount of relief given by each local authority is recorded. This means that the vacancy statistic will underestimate the total number and value of vacant property since some will only be receiving $50 \%$ relief as explained above. Therefore, an adjustment is made to estimate the total value of relief as if all premises had received 100\% relief regardless of how long they had been vacant. The assumptions underlying this adjustment are as follows. The amount of relief given to premises that are vacant for less than 3 months, and therefore receive $100 \%$ relief, is estimated. Based on more detailed information provided by several local authorities, it is estimated that on average $3 \%$ of all commercial and industrial property in a typical local authority area is likely to be vacant for less than 3 months at any time. Therefore $3 \%$ of the total gross rates payable is taken as an estimate of the amount of relief that is going to properties vacant for less than 3 months and this amount is deducted from the total relief, leaving a 'residual' relief given to premises vacant for more than 3 months. This residual relief figure is then adjusted to take into account that shops and offices are only permitted $50 \%$ relief. Using the Commercial and Industrial Floorspace and Rateable Value Statistics, it is possible to estimate how much of the residual relief is likely to be from each bulk class by assuming that the proportion of rateable value that relates to vacant properties will be the same within each bulk class. The relief given to retail and offices is then multiplied by two to provide an estimate of the true value of vacant premises. Finally the estimates of relief from short-term and long-term vacant from retail and offices, and long-term vacant from warehouses and factories are added together to give a total estimate of the value of properties in each local authority. The proportions of vacant properties are calculated by taking this total relief estimate as a percentage of the total Business Rate paid to the Government by the local authority. Although the vacancy statistics are not fully accredited-and are therefore referred to as 'experimental statistics' by the Office for National Statistics - they are available online (www.statistics.gov.uk). For England the percentage of commercial and industrial properties that were vacant in 2000/01 (April 2000-March 2001) was 7\%, and in 2001/02 and 2002/03 it was $8 \%$. For Leeds the respective figures were $9 \%, 10 \%$ and $11 \%$.

This 'experimental' vacancy statistic falls short of what is required, and the Government recently commissioned research into ways in which information about vacant commercial and industrial premises might be improved (ODPM, 2006b). The next section describes a case study that shows how improvements can 
be made in terms of recording the duration of vacancy episodes, identifying vacant premises at a larger geographical scale and analysing the key attributes of vacant commercial and industrial premises such as size, age and use.

\section{Case Study: Vacant Commercial and Industrial Property in Leeds}

The method of combining Business Rates information collected from the Valuation Office Agency and local authorities was described in Myers and Wyatt (2004) but has undergone some review and improvement since that time. The raw data on which the Commercial and Industrial Floorspace and Rateable Value Statistics are based undergo considerable processing before the generation of the statistics themselves. This involves imputing missing floorspace and reclassifying bulk classes in certain circumstances. More information on the methods of imputation is available in the annexes of Commercial and Industrial Floorspace and Rateable Value Statistics 1998-2004 (ODPM, 2005a). To retain compatibility with the published floorspace statistics, VOA floorspace data for Leeds that had already been processed for the floorspace statistics were used in this case study.

Episodes of vacancy falling between 1 April 2000 and 31 March 2004 were obtained from Leeds City Council. The codes that are used to record periods of exemption and relief from full rates liability do vary from authority to authority and are no doubt a result of the use of different billing systems. However, the reasons for which exemption or relief may be granted are laid down by statute and it is possible to define a set of codes that identify hereditaments that are:

- entitled to rates relief during an initial 3-month period of vacancy;

- legally prohibited from being occupied (e.g. premises in very poor condition and the local authority has prohibited occupation);

- empty and subject to major works;

- empty and the subject of Crown action (e.g. the hereditament has been compulsorily acquired and is standing empty);

- empty industrial property (includes factories, stores, warehouses and workshops);

- empty shops or offices;

- empty listed premises;

- empty and where the rateable value is under $£ 2,200$ in the 2005 Rating List.

Contiguous vacancy episodes were conflated into a single record and for this purpose a gap of up to 3 days was considered contiguous, but in most cases the gap was 1 day or less. This captures exemption and relief episodes where one is immediately followed by the other. This is fairly common in cases where hereditaments remain vacant beyond the end of the initial 3-month exemption period. The conflated vacancy periods were then each joined to the appropriate attribute information for each hereditament, maintained by the VOA. Basically, because the characteristics of a hereditament may change over time, perhaps a new floor is added or its use changes, a join process was devised that ensured that the correct version of the hereditament (referred to as an 'assessment' by the VOA) was joined to the vacancy information, in other words the assessment with a 
matching identification code, and which was the version current at the start of the vacancy period. If there was no vacancy period during a version (assessment) of a hereditament, then that assessment was flagged as fully occupied. If a vacancy period occurred during an assessment, then one of four possible cases were possible:

- Case 1: vacancy started on or before the start of the assessment period for a hereditament and finished on or after the end of the assessment period-in which case the assessment period was flagged as vacant for its full duration (see Figure 1).

- Case 2: vacancy started on or before the start of the assessment period and finished before the end of the assessment-in which case the assessment period was subdivided into two parts, the first flagged as vacant and the remainder as occupied (see Figure 2).

- Case 3: vacancy started after the start of the assessment period and finished on or after the end of the assessment-in which case the assessment period was subdivided into two parts, the first flagged as occupied and the remainder as vacant (see Figure 3).

- Case 4: vacancy started after the start of the assessment period and finished before the end of the assessment — in which case the assessment period was subdivided into three parts flagged successively as occupied, vacant and occupied (see Figure 4).

This process resulted in a chronological listing of all assessment periods for each hereditament, subdivided where appropriate to differentiate between occupied and vacant. For a more detailed explanation of the processing and join method, see ODPM (2006b). With the addition of calculated fields showing the length of each period and other attribute data from the VOA data (rateable value, floorspace, etc.), these records formed the core data set from which further analysis could be undertaken.

\section{Analysis}

Figure 5 shows the floorspace and rateable value of all hereditaments in Leeds for 2004. Factories had the largest total floorspace-albeit being the least in number (at 3,188) and having the lowest total rateable value-offices had the highest total rateable value and retail accounted for the largest number of hereditaments $(8,169)$, but these covered the least floorspace.

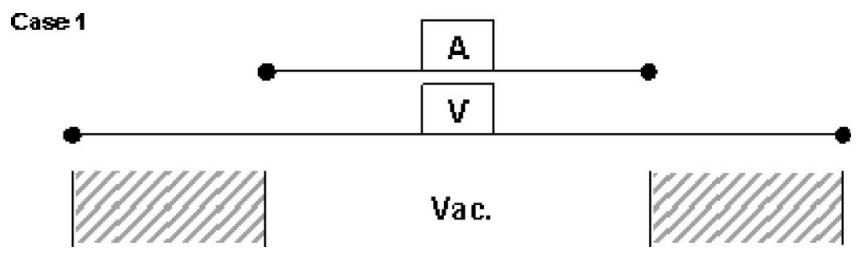

FIGURE 1. Case 1: vacant for full duration. 


\section{Mutale Katyoka \& Peter Wyatt}

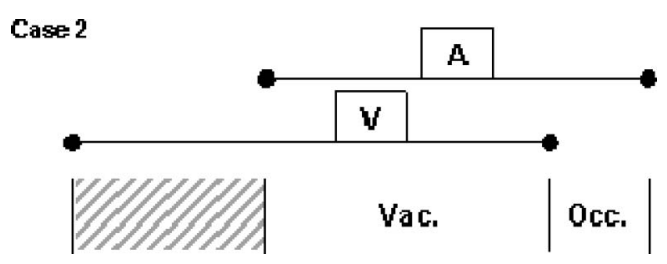

FIGURE 2. Case 2: vacant and then occupied.

Case: 3

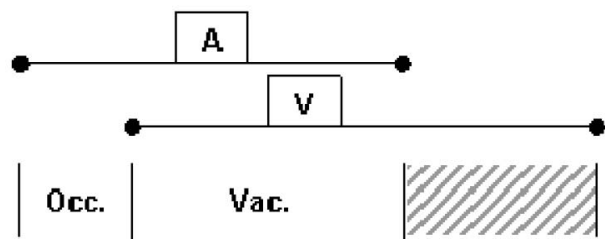

FIGURE 3. Case 3: occupied and then vacant.

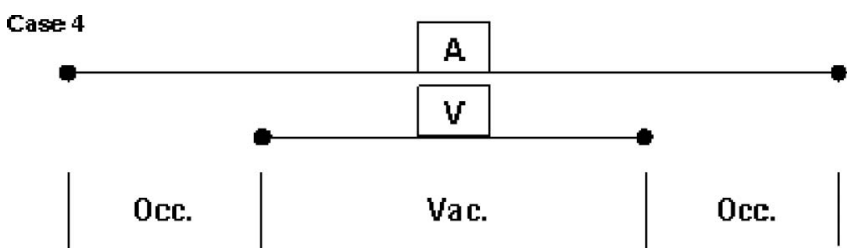

FiguRE 4. Case 4: occupied, vacant and then occupied again.

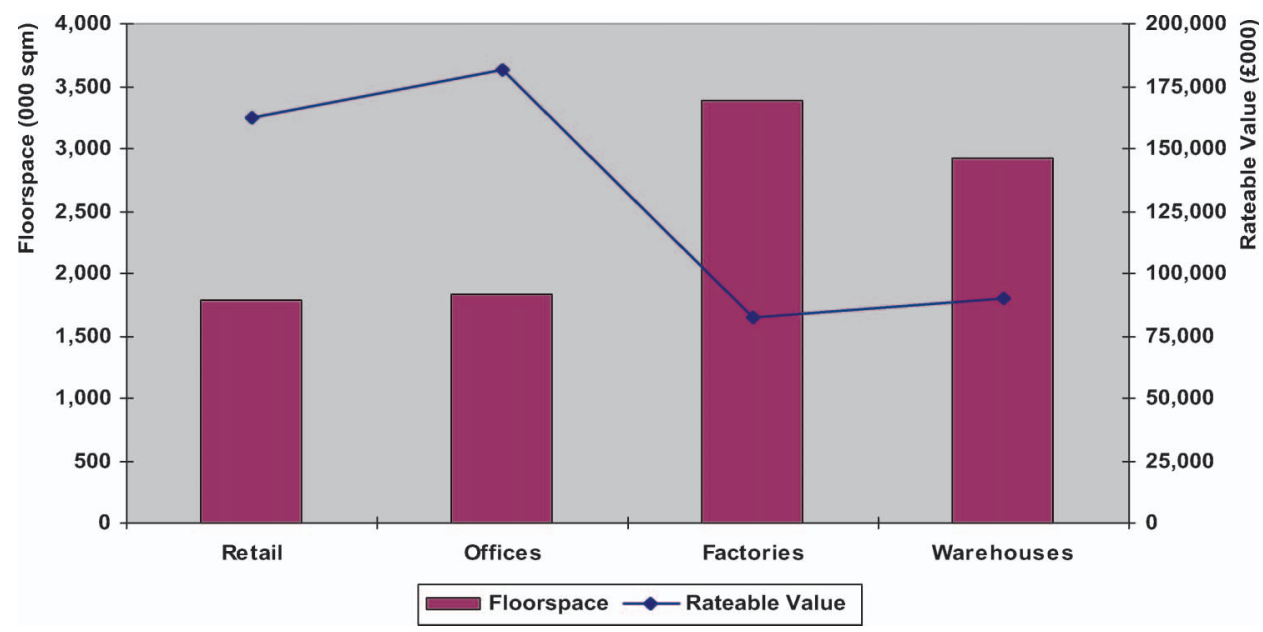

FIGURE 5. Floorspace and rateable values for all Leeds hereditaments. 
Figure 6 examines vacant floorspace and rateable values for 2004. Thirteen per cent $(2,678)$ of all bulk class hereditaments in Leeds were vacant, representing $10 \%$ and $9 \%$ of the total floorspace and rateable values, respectively. Thirty-four per cent of vacant hereditaments were offices, accounting for the highest overall rateable value. Retail accounted for $25 \%$ of all vacant hereditaments but had the least floorspace and rateable value in absolute terms. Factories had the lowest proportion of vacancy (20\%) but covered the largest floorspace because they typically consist of larger units compared with office or retail units and the rateable value per square metre is usually low.

Figure 7 presents the proportion of vacant hereditaments at bulk class level. Factories had the highest rate $(17.03 \%)$ and retail had the lowest $(8.13 \%)$, almost less than one-half of the others. There was, however, a higher proportion of total vacant offices in terms of floorspace and rateable values than any other sector.

Further analysis was undertaken using the length of vacancy by categorizing the vacancy durations into periods of 6 months up to 31 December 2003. For example, hereditaments that fall within the 12-month period of vacancy are those that became vacant between 1 December 2002 and 31 July 2003 and were still vacant on 31 December 2003. So these properties had been vacant for more than 6 months but less than 12 months. It was interesting to see, for example, how many hereditaments had been vacant up to 6 months, 12 months, and so on (36 months being the maximum), as illustrated in Figure 8. It should be noted that these periods of vacancy do not overlap and the figures can therefore be aggregated.

Table 1 presents the number of vacant hereditaments in Leeds in relation to all hereditaments for each period of vacancy.

Overall, the number of vacant hereditaments as a proportion of total hereditaments reduced as the period of vacancy increased, as shown in Figure 9.

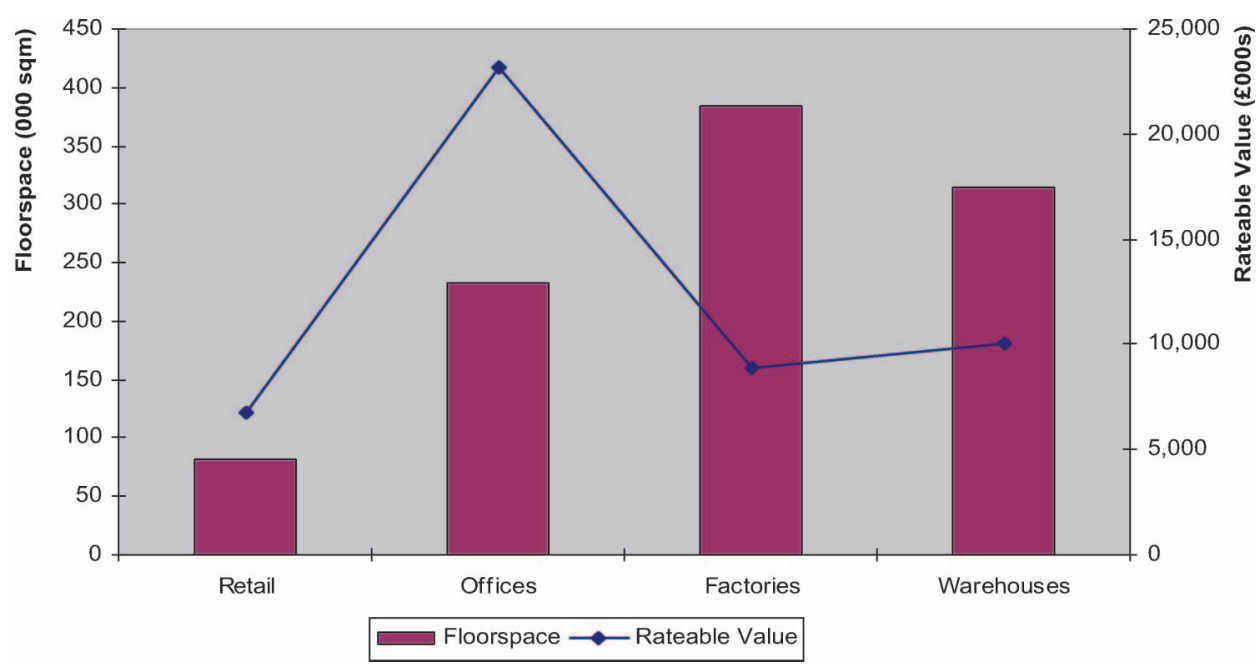

FIGURE 6. Leeds vacant hereditament floorspace and rateable values. 


\section{Mutale Katyoka \& Peter Wyatt}

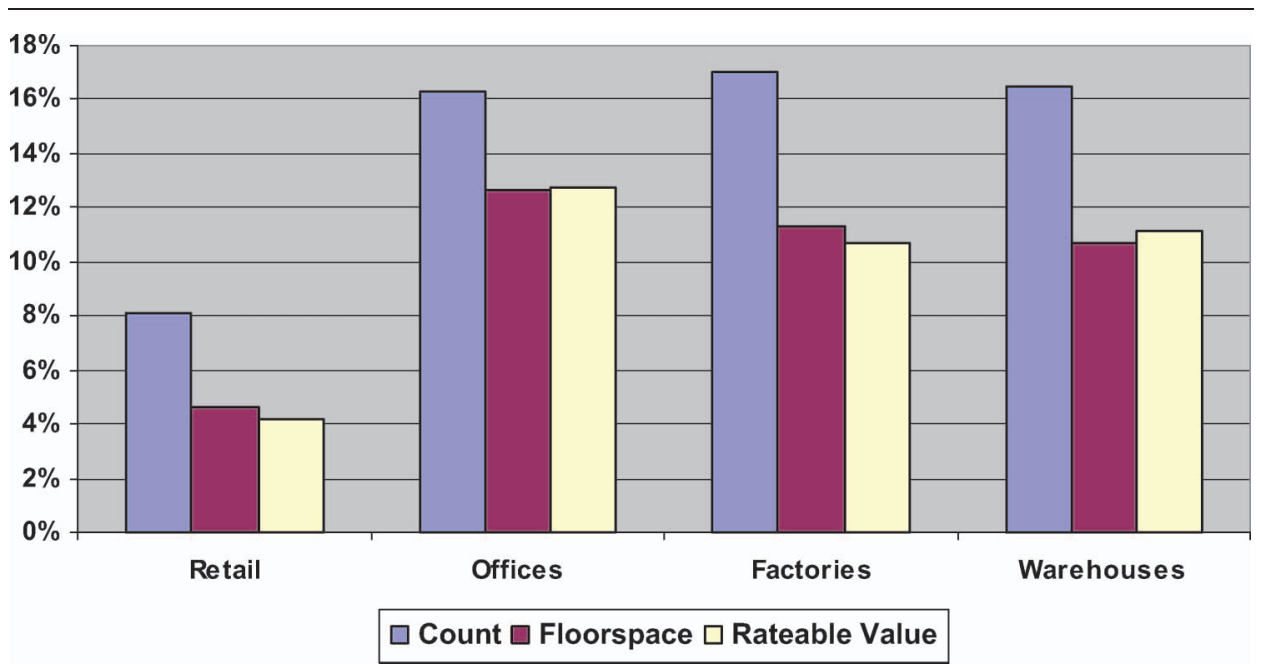

FIGURE 7. Percentage of vacant hereditaments in Leeds.

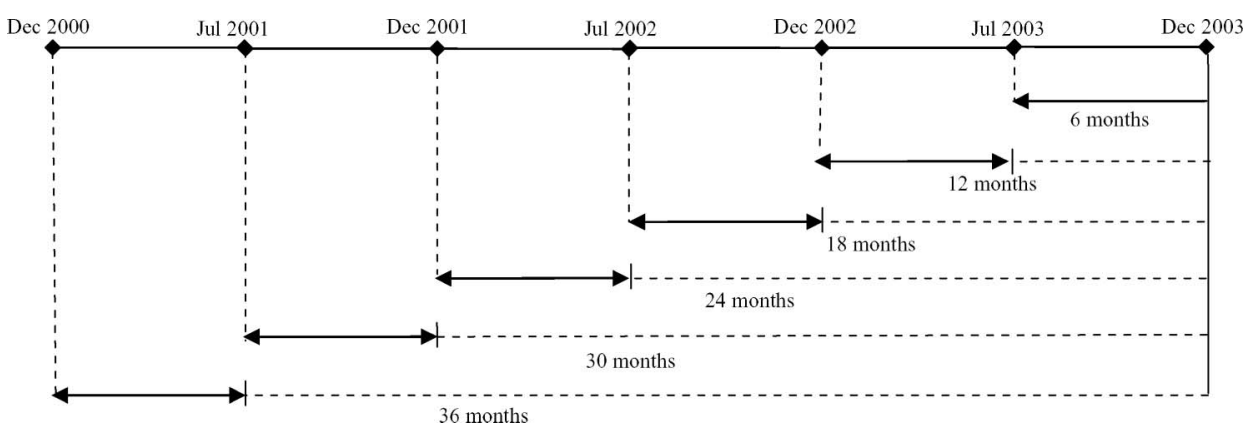

FIGURE 8. Periods of vacancy.

TABLE 1. Number of vacant hereditaments (percentage of all hereditaments) in Leeds

\begin{tabular}{|c|c|c|c|c|c|c|c|}
\hline \multirow[b]{2}{*}{$\begin{array}{l}\text { Property } \\
\text { type }\end{array}$} & \multirow[b]{2}{*}{$\begin{array}{c}\text { All } \\
\text { hereditaments }\end{array}$} & \multicolumn{6}{|c|}{ Vacant hereditaments per period of vacancy } \\
\hline & & $\begin{array}{c}6 \\
\text { months }\end{array}$ & $\begin{array}{c}12 \\
\text { months }\end{array}$ & $\begin{array}{c}18 \\
\text { months }\end{array}$ & $\begin{array}{c}24 \\
\text { months }\end{array}$ & $\begin{array}{c}30 \\
\text { months }\end{array}$ & $\begin{array}{c}36 \\
\text { months }\end{array}$ \\
\hline Sho & 8, & $\begin{array}{c}246 \\
(3.01 \%)\end{array}$ & $\begin{array}{c}162 \\
(1.98 \%)\end{array}$ & $\begin{array}{c}97 \\
(1.19 \%)\end{array}$ & $\begin{array}{c}58 \\
(0.71 \%)\end{array}$ & $\begin{array}{c}51 \\
(0.62 \%)\end{array}$ & $\begin{array}{c}50 \\
(0.61 \%)\end{array}$ \\
\hline Offices & 5,614 & $\begin{array}{c}325 \\
(5.79 \%)\end{array}$ & $\begin{array}{c}194 \\
(3.46 \%)\end{array}$ & $\begin{array}{c}155 \\
(2.76 \%)\end{array}$ & $\begin{array}{c}110 \\
(1.96 \%)\end{array}$ & $\begin{array}{c}74 \\
(1.32 \%)\end{array}$ & $\begin{array}{c}55 \\
(0.98 \%)\end{array}$ \\
\hline Warehouses & 3,385 & $\begin{array}{c}149 \\
(4.67 \%)\end{array}$ & $\begin{array}{c}125 \\
(3.92 \%)\end{array}$ & $\begin{array}{c}91 \\
(2.85 \%)\end{array}$ & $\begin{array}{c}74 \\
(2.32 \%)\end{array}$ & $\begin{array}{c}60 \\
(1.88 \%)\end{array}$ & $\begin{array}{c}59 \\
(1.85 \%)\end{array}$ \\
\hline Factories & 3,188 & $\begin{array}{c}147 \\
(4.34 \%)\end{array}$ & $\begin{array}{c}115 \\
(3.40 \%)\end{array}$ & $\begin{array}{c}80 \\
(2.36 \%)\end{array}$ & $\begin{array}{c}83 \\
(2.45 \%)\end{array}$ & $\begin{array}{c}58 \\
(1.71 \%)\end{array}$ & $\begin{array}{c}60 \\
(1.77 \%)\end{array}$ \\
\hline $\begin{array}{l}\text { All bulk } \\
\text { classes }\end{array}$ & 20,356 & $\begin{array}{c}867 \\
(4.26 \%)\end{array}$ & $\begin{array}{c}596 \\
(2.93 \%)\end{array}$ & $\begin{array}{c}423 \\
(2.08 \%)\end{array}$ & $\begin{array}{c}325 \\
(1.60 \%)\end{array}$ & $\begin{array}{c}243 \\
(1.19 \%)\end{array}$ & $\begin{array}{c}224 \\
(1.10 \%)\end{array}$ \\
\hline
\end{tabular}


This is also true at bulk class level with the exception of factories, which show some fluctuations as illustrated in Figure 10. A chi-square test of association revealed that there was a relationship between the property types and the categorized vacancy periods (test statistic 53.09, which is greater than the $p$ value of 37.70 with 15 degrees of freedom at a significance level of 0.001 ).

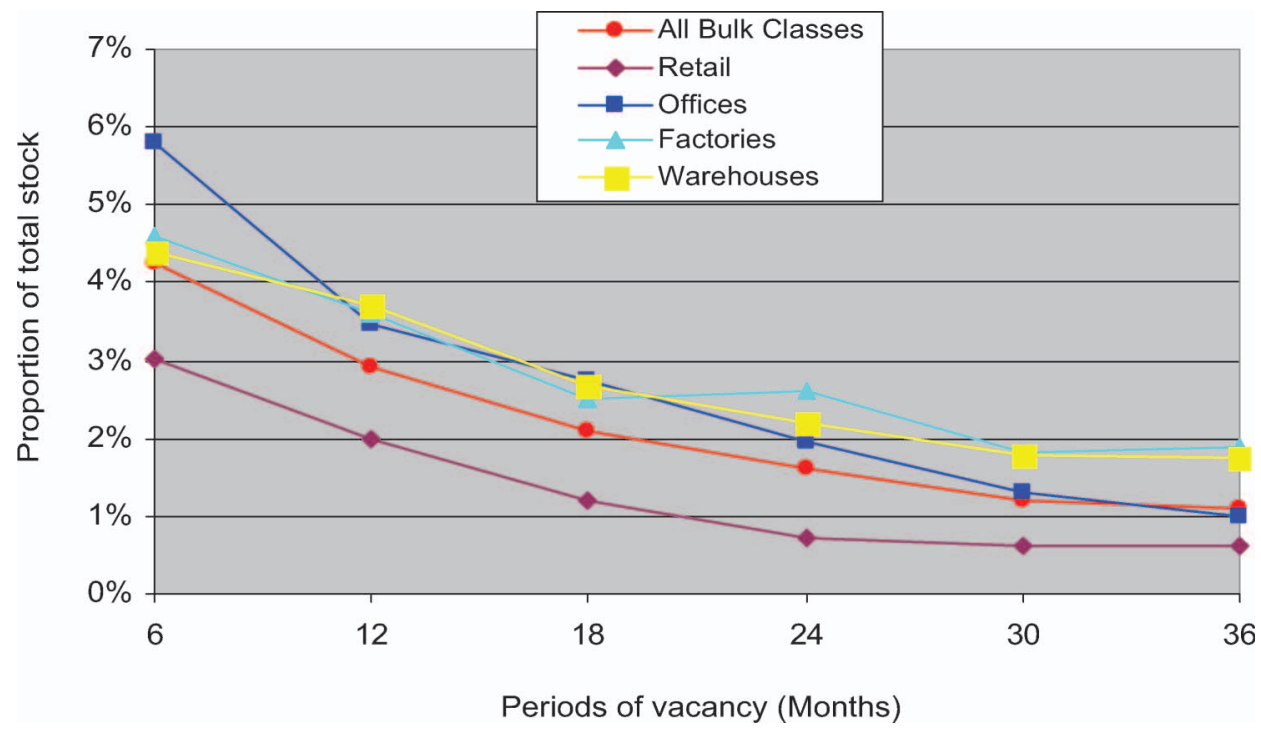

FIGURE 9. Vacant commercial and industrial hereditaments.

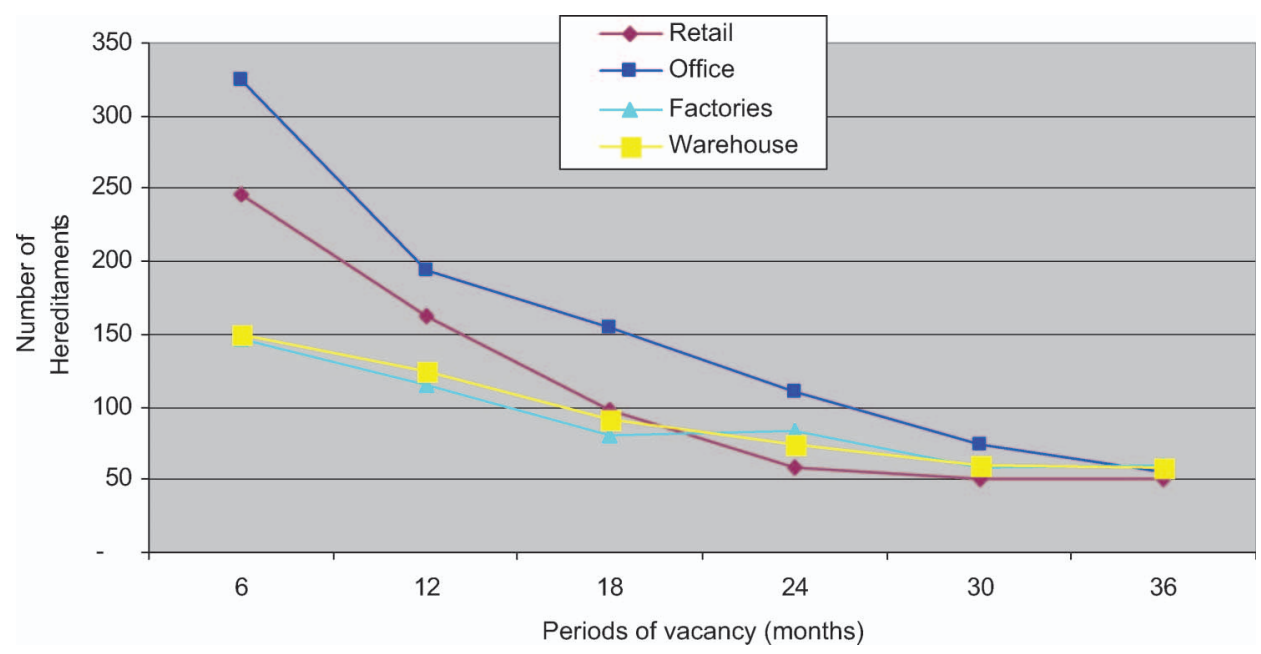

FIGURE 10. Number of hereditaments for bulk classes. 
Figure 11 reveals that vacant office floorspace reduced with increasing periods of vacancy. Retail and factory floorspace also show a similar trend; however, both increased slightly in the 31-month to 36-month vacancy period. The amount of vacant warehouse space fluctuated markedly over the periods. Overall, all property types seem to have had steeper decreases in the first two or three periods of vacancy and then levelled off in the last two.

Over the six periods of vacancy, total office rateable values showed a dramatic reduction - an average drop of $40 \%$ in the first two periods and $31 \%$ in the last two periods (see Figure 12). Warehouse rateable values also reduced for the first five periods at an average rate of $27 \%$ but there was a slight increase in the period of vacancy. There was a sharp decrease in the rateable values of retail between the 6 -month to 18 -month periods of vacancy, the biggest decrease being by $57 \%$ between 12 and 18 months periods of vacancy. For the remaining periods of vacancy, reductions for retail were at a reduced rate (an average of 14\%). Rateable values for factories fluctuated significantly over all the six periods of vacancy. The biggest decrease was $81 \%$ between the 30 -month and 36 -month vacancy period.

Figure 13 shows the proportion of hereditaments vacant for specific periods by bulk class for all the age bands-these age bands are consistent with ODPM (2006a). In each age group, retail had the least proportion of vacant hereditaments. For the pre-1940 hereditaments, factories had the highest proportion of vacancy, followed by warehouses and then offices. Between 1940-1970 and 1981-1990 offices had the highest proportion, but in the 1991-2000 range the proportion of offices dropped below that of warehouses and factories. For the more recently built (2001-2003) hereditaments, factories had the highest proportion of vacancy

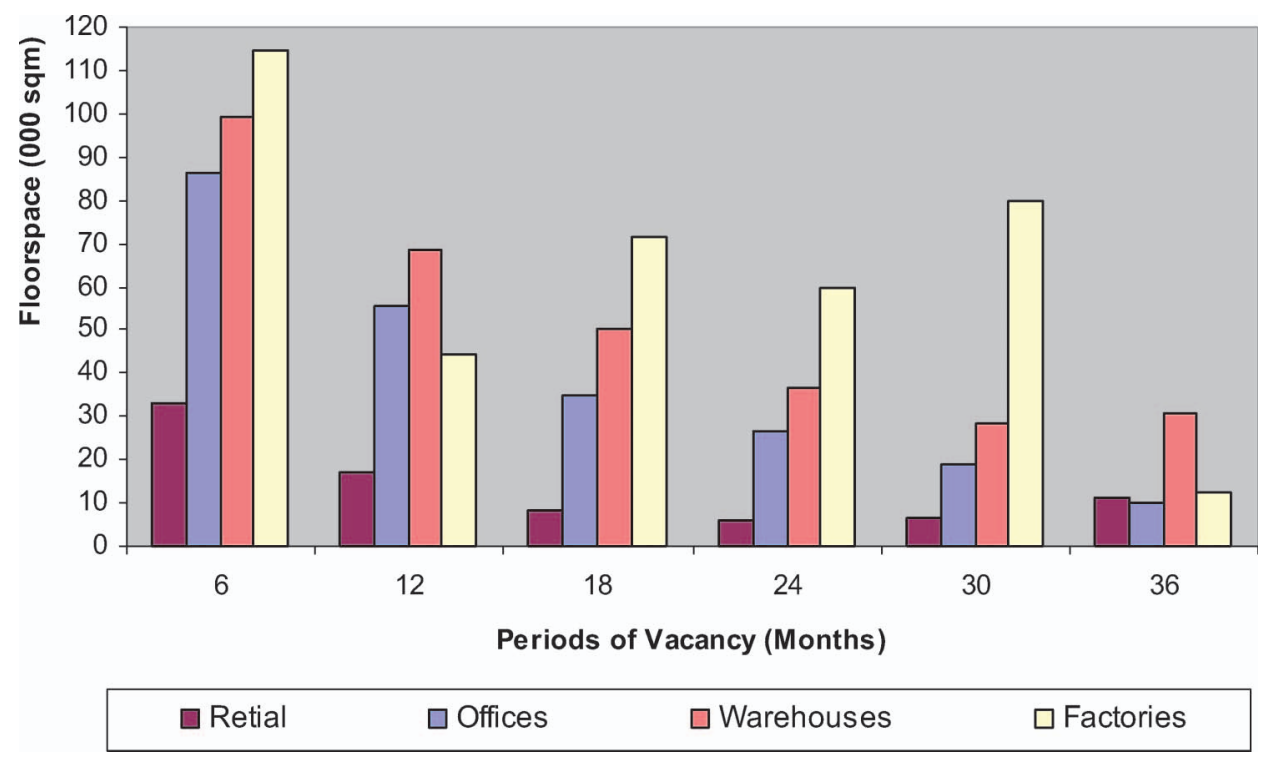

FIGURE 11. Floorspace for periods of vacancy. 


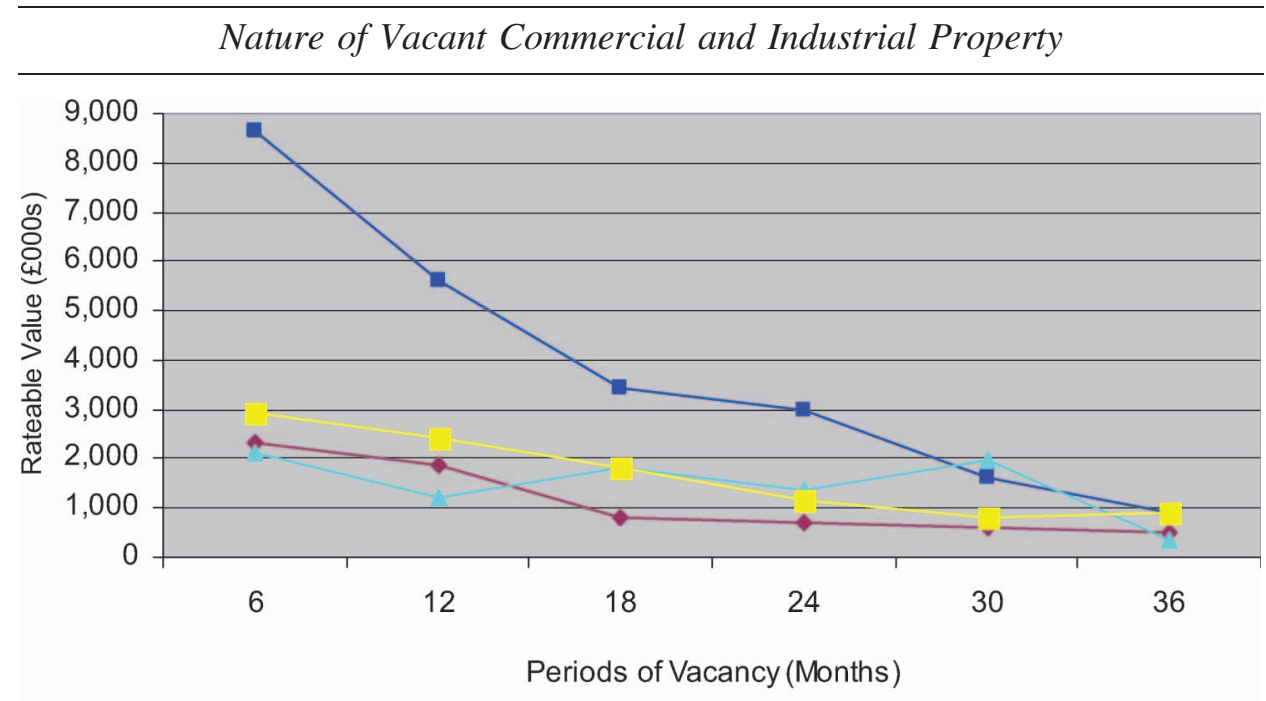

$\longrightarrow$ Retail $\rightarrow$ Offices $\longrightarrow$ Factories - Warehouses

FIGURE 12. Rateable values for periods of vacancy.

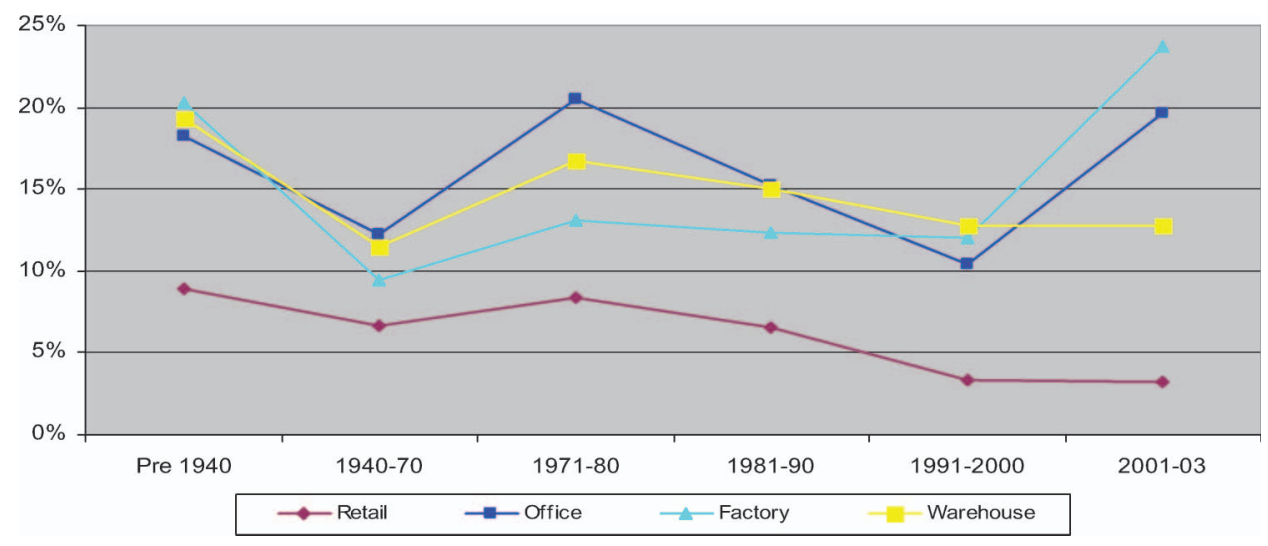

FIGURE 13. Proportion of vacant hereditaments to all Leeds hereditaments by age.

followed by offices and then warehouses. An increase in the proportion of vacant offices and factories since the early 1990s is clear to see.

Figures 14 and 15 show the actual breakdown of floorspace and rateable values, respectively, for bulk classes over the age ranges.

Owing to some VOA disclosure rules, floorspace data at local authority level for the age group 2001-2003 could not be disaggregated by property type (ODPM, 2006a). Figure 16, however, shows the proportion for other age groups. Factories, followed by offices, show the highest proportions of floorspace in the pre-1940 and 1981-1990 age groups. Factories have their lowest proportions in 1940-1970 age range, and offices in the 1991-192000. For all of the age ranges, retail has the 


\section{Mutale Katyoka \& Peter Wyatt}

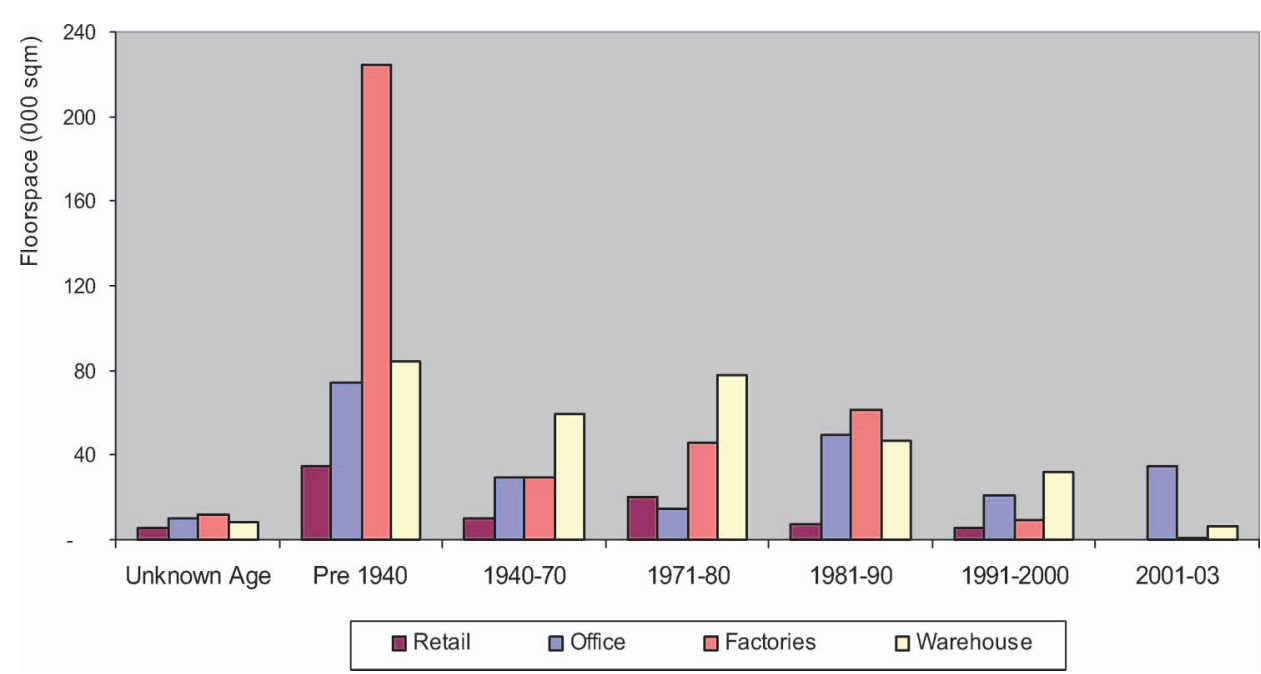

FIGURE 14. Property type floorspace for vacant hereditament age profiles.

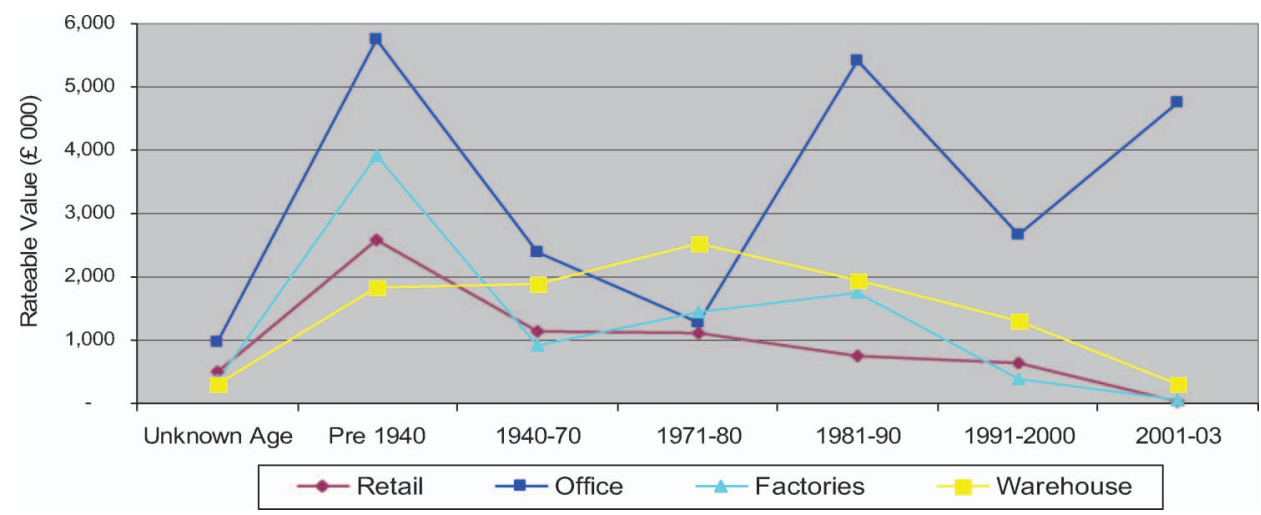

FIGURE 15. Property type rateable values for vacant hereditament age profiles.

lowest proportion of floorspace. Warehouses had the biggest proportion in the 1970-1980 age group. Its lowest proportion was in 1991-2000 even though this was higher than the other property types in this age group.

Finally, it is useful to examine the location of vacant commercial and industrial premises but there are a few geographical considerations that should be borne in mind before doing so. First, the spatial distribution of business premises is nonuniform; quite simply, we expect to find much greater numbers of premises in urban areas than in rural areas, and central urban areas would obviously have a higher number of premises than peripheral urban areas. So if the distribution of vacant premises is mapped, we will clearly find clusters that correspond to this pattern. This non-uniformity of space (O'Sullivan \& Unwin, 2003) must be 


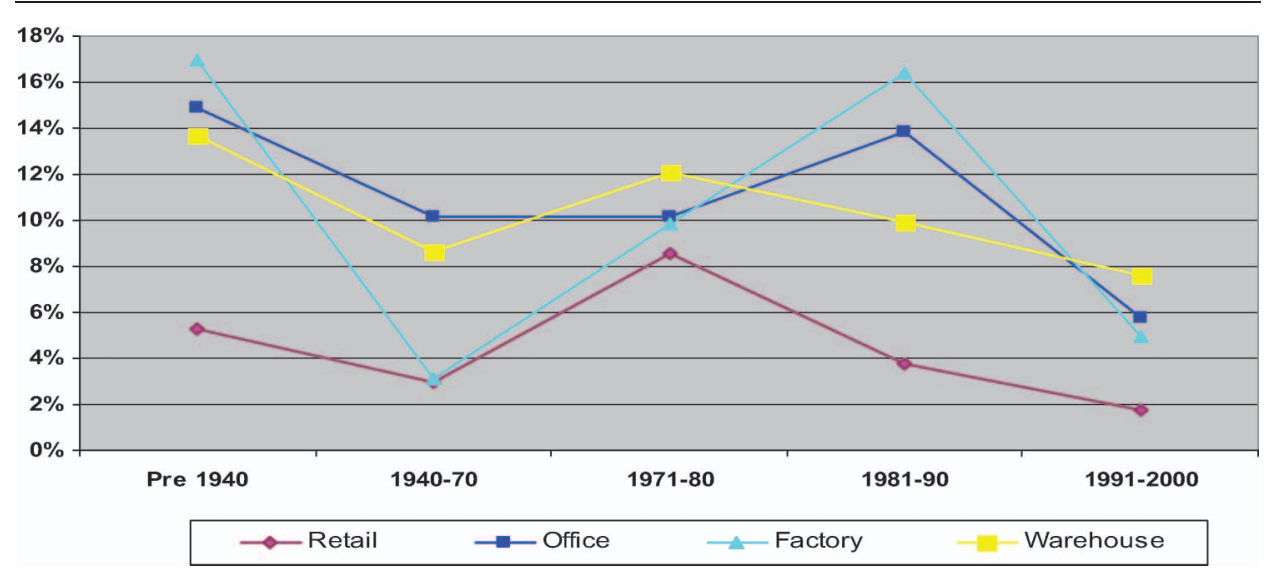

FIGURE 16. Proportion of vacant floorspace to all Leeds hereditaments by age group for property types.

expected when analysing data gathered about human geography at high resolution. Figure 17 shows the urban areas in Leeds, shaded light grey as delineated by the Ordnance Survey, and these areas include residential as well as commercial land uses and encompass open spaces that are completely surrounded by built-up areas. The town-centre boundaries, on the other hand, as defined by the ODPM (2005d), are shaded dark grey and these delineate the extent of the retail areas within Leeds. We could legitimately expect clusters of vacant premises in these areas because the represent they highest density of commercial premises as a whole.

Second, care must be exercised over the way in which vacant premises are mapped. A popular way of mapping human geography data sets is to use choropleth maps, but none of the subdistrict area boundaries use the distribution of business premises to define them. Most are based on the distribution of resident population (electoral wards and census output areas are the most commonly used), and Figure 18 shows the sort of thing that can happen when census output areas (medium super output areas in this case) are used to display the number of local business units in Leeds. The area stretching south east from the centre of Leeds contains a high number of business units but, as the overlaid density map shows, the vast majority of hereditaments are located in the northern part, in the central urban area.

Bearing these issues in mind the method chosen to examine the location of vacant premises was density mapping. This process takes a set of point features and converts them to a cellular grid, where each cell is given a value based upon the density of features in its vicinity. The density of point locations can be mapped using simple or kernel calculations, and the latter method was used here. In the kernel density calculation a smooth curved surface was fitted over each point based on a quadratic function. The surface value is highest at the location of the point, and diminishes with increasing distance from the point, reaching 0 at the search radius distance from the point. The volume under the surface equals the attribute value for the point (count, floorspace or rateable value in this case). The 


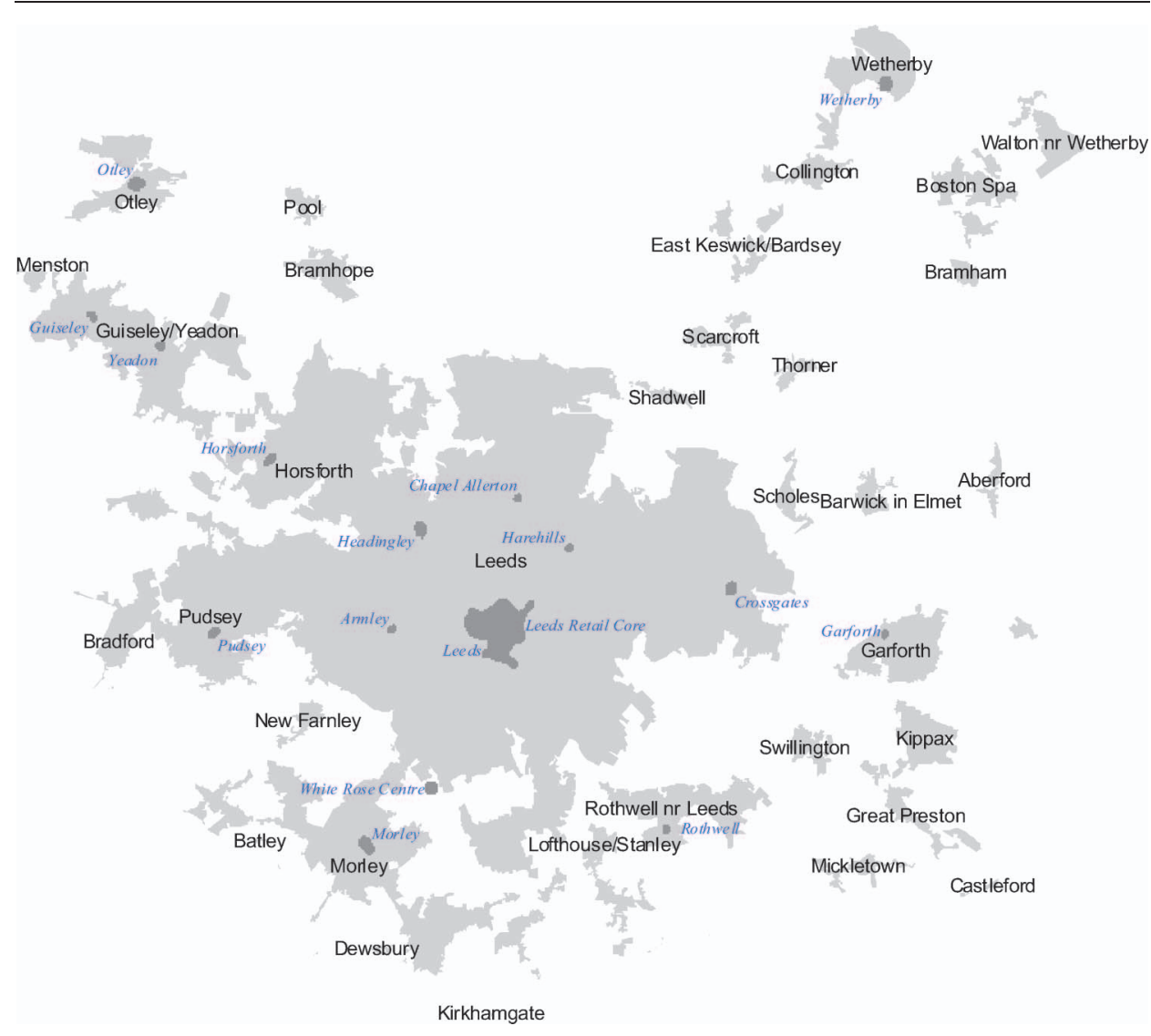

FIGURE 17. Urban areas and commercial districts in Leeds.

density at each output raster cell is calculated by adding the values of all the kernel surfaces where they overlay the raster cell centre. The density of vacant commercial and industrial premises was mapped in terms of number of hereditaments and in terms of floorspace. Figure 19 shows the location of premises that have been vacant for at least 3 years as of 31 March 2004, and it can clearly be seen that these are concentrated in the city centre with a small secondary cluster to the east of Pudsey. However, when the density of vacant floorspace is mapped a different picture emerges. Figure 20 shows multiple locations. So the geographical picture of vacant commercial premises varies depending on the variable that is measured. In terms of numbers of hereditaments the many vacant shops and offices in the city centre predominate, but in terms of floorspace the fewer but larger vacant factories and warehouses outside of the central business district are brought to the fore.

Focusing on the clusters of vacant premises in the city centre and in a semicircle of locations to the west, south and east of the centre, Figure 21 shows the location of premises that have been vacant for at least 3 years by property type. The concentration of vacant shops and offices in the city centre (bounded by the 

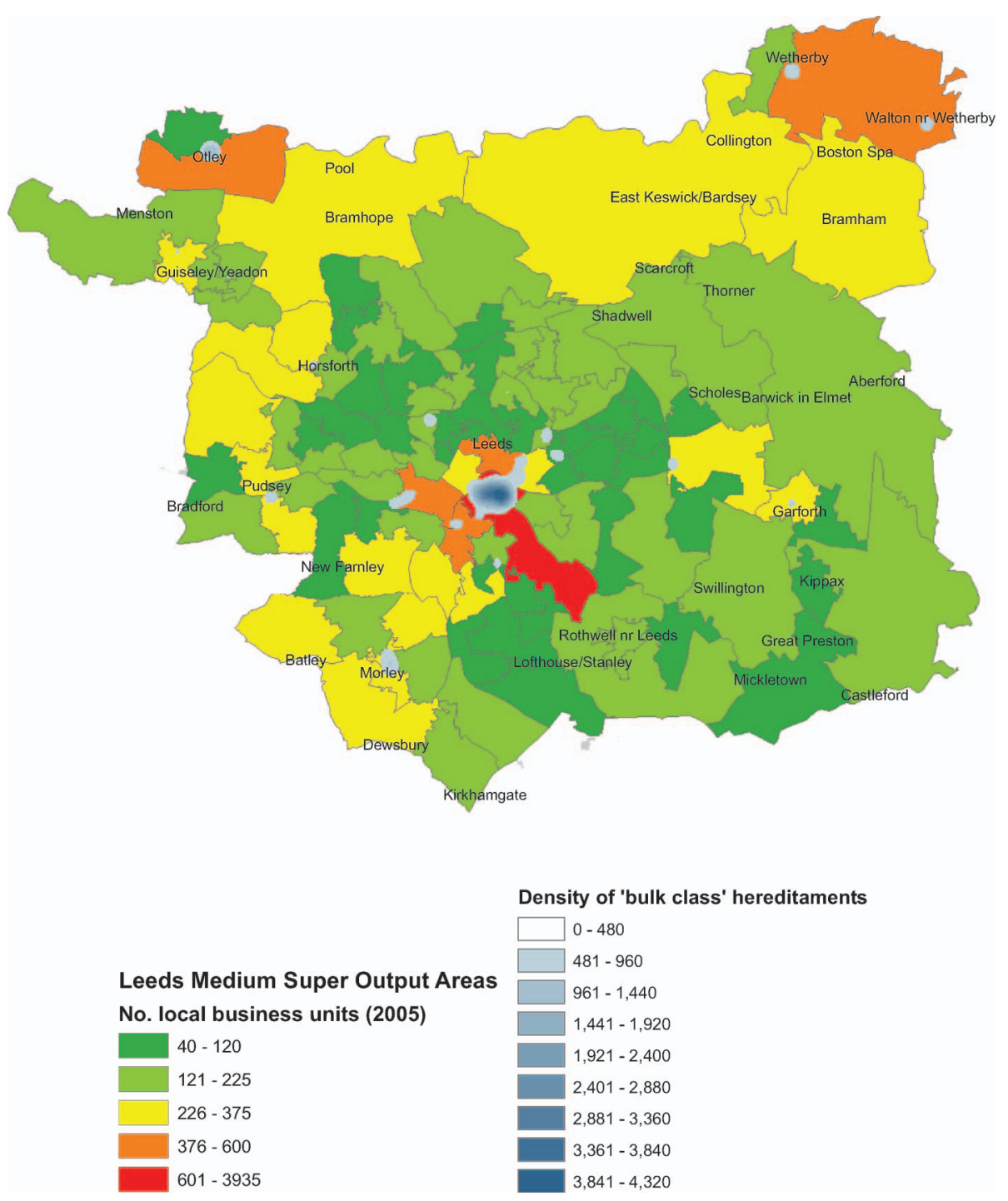

FIGURE 18. 'Density' counts the number of hereditaments in a kernel search area centred at each location in the Leeds study area.

dark grey rectangle) is clear. The outer clusters are predominantly factories and warehouses apart from the large vacant retail warehouse labelled (1) on the map. As above, the density surface shows where the larger vacant premises are located. On the map there are 21 empty shops outside the city centre. Excluding the two retail warehouse premises, these are small district units with an average floorspace of 68 square metres and an average rateable value of $£ 3,875$. Compare this with the shops in the city centre, which have an average floorspace of 133 square metres and an average rateable value of $£ 19,000$. 


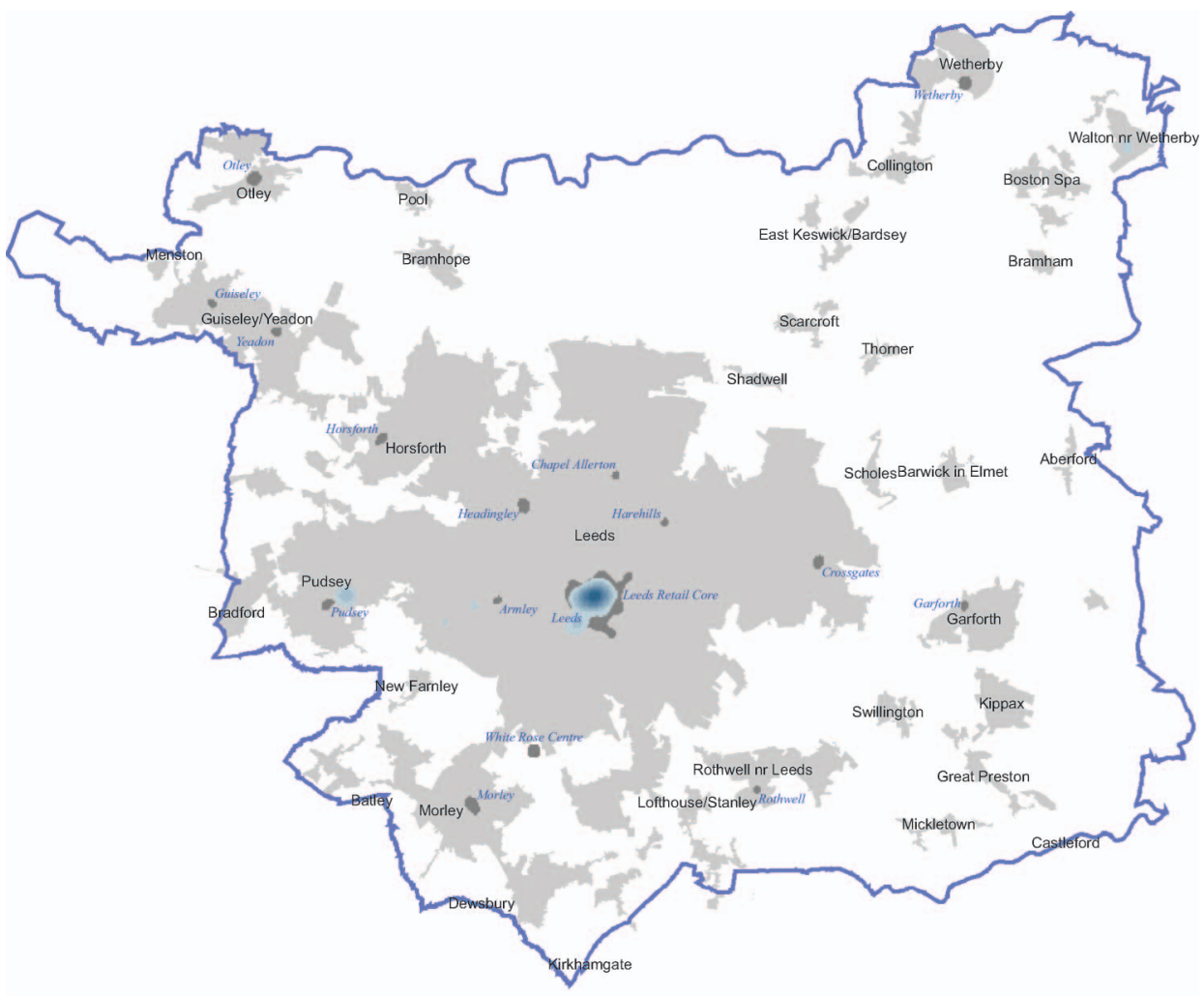

Density of three-year vacancies Number of hereditaments

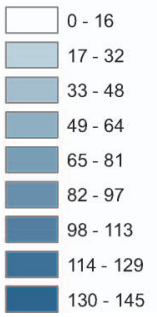

FIGURE 19. Density of three-year vacancies (number of hereditaments).

\section{Implications}

Although vacancy may seem at first sight to be a relatively simple concept, on closer examination it takes on a complexity that needs to be unravelled before drafting and implementing national and local policy. A briefly vacant unit in an office building is different from a factory that has been empty for some years. There are different types of vacancy, with different implications for the region in which they occur and the economy in general. The definition of vacancy is important to the interpretation of statistics, and different agencies will have 


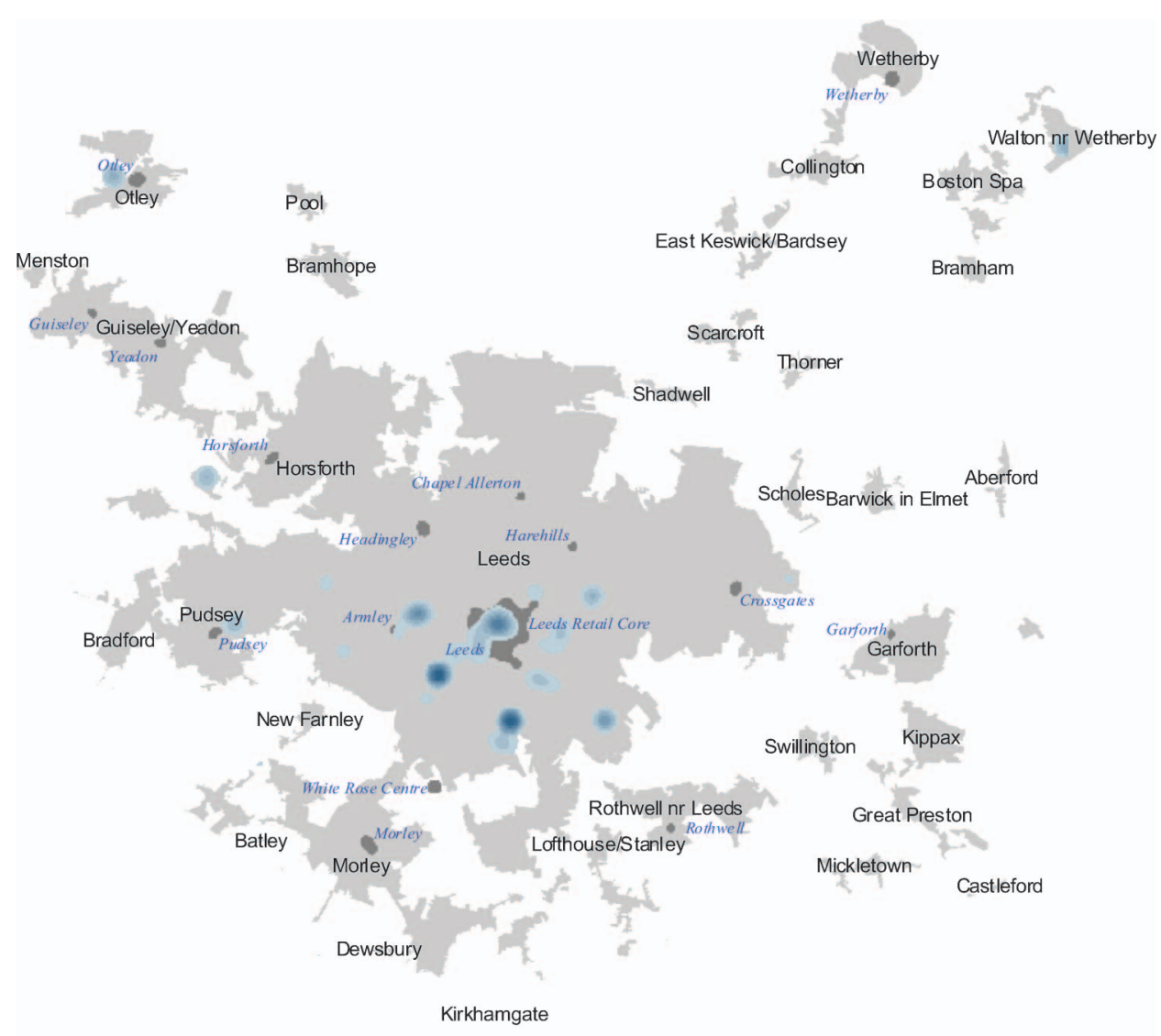

Density of three-year vacancies

Floorspace (square metres)

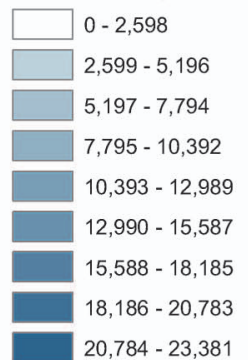

FIGURE 20. Density of three-year vacancies (floorspace).

different viewpoints about what kinds of vacancy are important to them. In some circumstances the definition may affect the accuracy of the statistics. It is important to ensure that different types of vacancy do not get bundled together in a variable and unknown manner according to local procedures, which then prevents reliable 


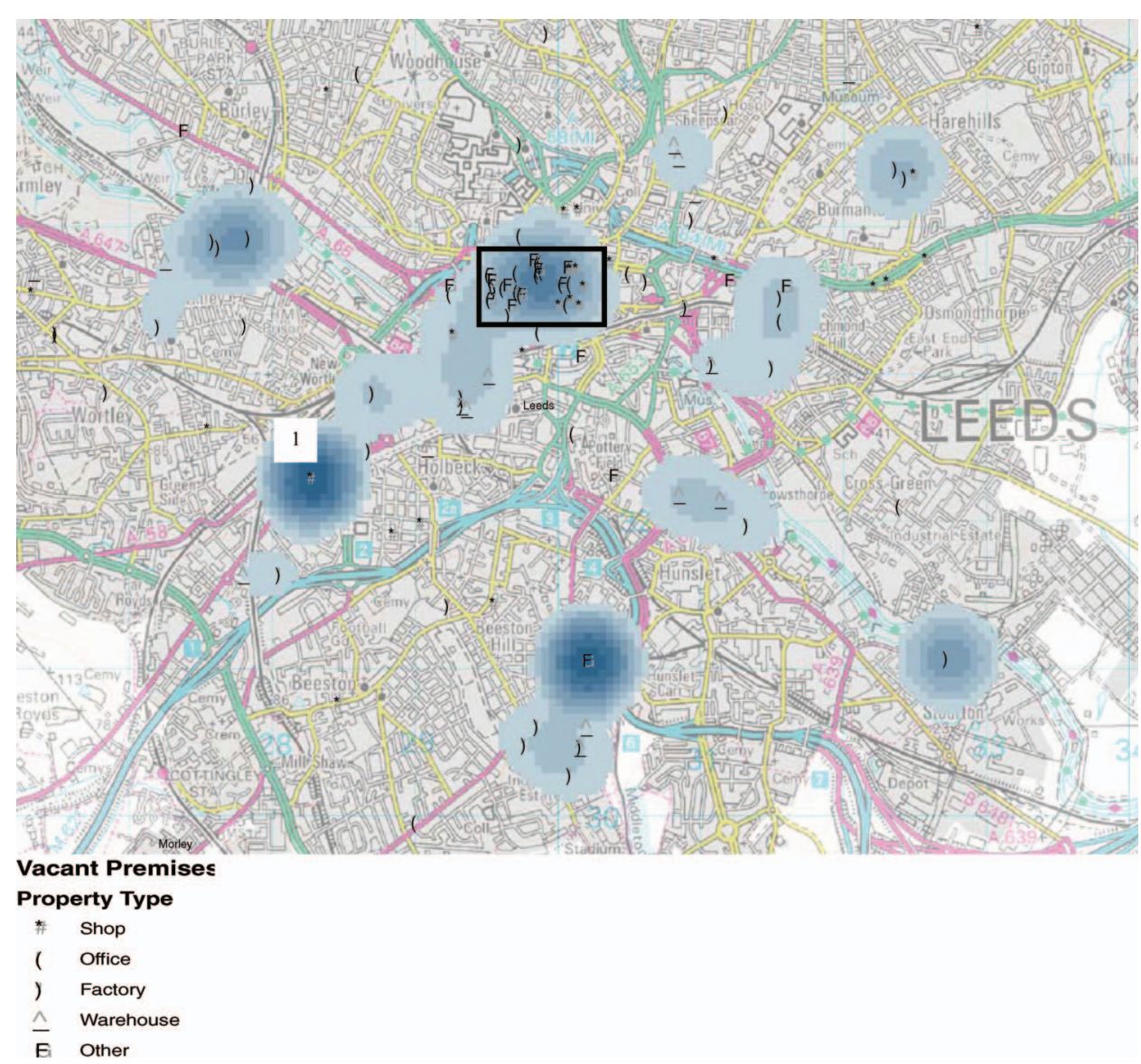

FIGURE 21. Three-year vacancies by property type.

regional and local comparisons of vacancy rates. For instance, Neighbourhood Regeneration initiatives may not require quite the same data as those in government monitoring the health of the financial industry. A vacant property in planning terms may not represent a change of use and is thus of limited importance, but to an economic development department vacancy is key information.

A distinction should be drawn between short and long periods of vacancy. As is the case in the residential property market, it would not be unreasonable to assume periods of vacancy to be associated with 'churn' or friction in the market as buyers and sellers transact. Indeed, because for approximately one-half of the stock of commercial property there is a separation between occupation and ownership (landlords let premises to tenants), periods of vacancy might be more frequent as lettings occur more frequently than in the housing market, which is $70 \%$ owner-occupied and owners tend to move less frequently. Similarly it is not unreasonable to expect premises to be vacant while undergoing refurbishment; indeed, relief from business rates can be claimed while such work is carried out. Premises that are vacant between lettings and sales or being refurbished represent 
a natural friction in the property market (Merrett \& Smith, 1986). Should such premises therefore be included in a statistic that reports long-term vacancy? If not, then a more sophisticated measure of the duration of dwelling vacancy is required - and this paper has described one approach to achieving this. If premises that have been vacant for a long time are to be a specific target of government policy then it is necessary to select an appropriate definition of long-term vacancy and remove from further analysis those vacant premises that fail to meet this definition. This is, in effect, the distinction that is made in the English House Condition Survey between transactional and structural vacancy in the residential property market. This research has shown that it is possible to use business rates data to record the length of time for which business premises have been vacant.

The density map shows the location of clusters of long-term vacant premises. This is important because it provides a focus for regeneration activity; a central theme of several Government policies. The Government's Sustainable Communities Plan, which was launched in 2003 to coordinate policies for building sustainable urban areas, requires appropriate indicators and measures of vacancy to describe the social and economic condition of urban areas and potential for future development. Public Service Agreement Target 5 sets out the objective to manage the supply and release of land for housing and other development while protecting greenfield land. This builds on the existing planning framework provided by Planning Policy Guidance Note 3: housing that gives priority to reusing previously developed land within urban areas, bringing empty buildings back into use and converting existing buildings in preference to the development of greenfield sites. Vacant buildings represent an important subcategory of previously developed land as defined by Planning Policy Guidance Note 3 and provide a valuable source of capacity for redevelopment.

Allied to Planning Policy Guidance Note 3 is the work of English Partnerships, the Government agency tasked with encouraging the regeneration of previously developed land in England. To assist this function it collects information on vacant land and buildings each year from local authorities. The resultant dataset, known as the National Land Use Database, aims to provide a consistent, comprehensive and up-to-date record of vacant and derelict sites and other previously developed land and buildings that may be available for redevelopment. Data collection is dependent on local planning authorities, who each year are requested to complete comprehensive returns detailing land use within their jurisdictions. This is a timeconsuming and resource-intensive task and a significant number of local authorities have been unable to respond positively, particularly with regard to vacant buildings and partial vacancy within buildings. By improving information available to local planners on building vacancies, this research could solve the problems of identifying vacant commercial buildings and boost the amount of non-domestic vacant buildings identified in future National Land Use Database returns.

At a more local level, vacancy information should be available to inform development and redevelopment decisions on a site-specific basis. For example, if a cluster of vacant buildings was characterized by a very high proportion of old property, then redevelopment might be a better option than refurbishment and this analysis might help with this judgement. It should also be capable of being aggregated to subregional, regional and national levels for monitoring and 
statistical analysis purposes. This will enable the proper monitoring of land supply and will help inform the planning process on the requirements for land release.

The ability to switch between broad-scale statistical analysis and micro-location analysis of vacant commercial premises using the same data source is a powerful characteristic of this data set. The primary statistical outputs are the number, size and value of non-domestic hereditaments that are vacant over a specified period of time. To put these figures into context, they can be expressed as vacancy rates within specified geographical areas such as wards or census output areas. In this way the statistics would form a subset of the annual commercial and industrial floorspace statistics that report the number of hereditaments, their floorspace and rateable value each year classified by use (bulk class) and by location. Investigating vacant hereditaments by making use of various attribute data such as bulk class, period of vacancy and age profile provides a better insight and understanding of the nature of vacant commercial and industrial premises.

The two principal benefits of the vacancy data are the ability to map vacancy up from postcode level to any bespoke or standard geography and to calculate the duration of vacancy. It is therefore possible to determine the intra-urban location and type of premises that have short-term vacancy churn (which might be seen as being indicative of above-average economic activity), and those that are vacant for long periods (which may be seen as a less positive effect).

\section{Acknowledgements}

The project was commissioned by the Office of the Deputy Prime Minister and undertaken by a research team led by the University of The West of England. The team comprised Harry Bruhns (University College London), Andrew Harrison (LandInform Ltd), Hugh Neffendorf (University of Southampton), Peter Wyatt (University of the West of England) and Bruce Yeoman (EGIC Ltd). The research team is grateful for the assistance and contribution of four local authoritiesLeeds, Tandridge, Reigate and Banstead and Huntingdonshire-who agreed to be involved in the project.

\section{References}

Bruhns, H. (2000) Property taxation data for nondomestic buildings in England and Wales, Environment and Planning B: Planning and Design, 27(1), pp. 33-49.

Bruhns, H., Steadman, P., Herring, H., Moss, S., \& Rickaby, P. (2000) Types, numbers, and floor areas of nondomestic premises in England and Wales, classified by activity, Environment and Planning B: Planning and Design, 27(4), pp. 641-665.

Department of the Environment (1988) Vacant Urban Land: A Literature Review 1976-86 (London: Department of the Environment, HMSO).

Merrett, S., \& Smith, R. (1986) Stock and flow in the analysis of vacant residential property, Town Planning Review, 57(1), pp. 51-67.

Myers, D., \& Wyatt, P. (2004) Rethinking urban capacity: identifying and appraising vacant buildings, Building Research \& Information, 32(4), pp. 285-292.

ODPM (2005a) Commercial and Industrial Floorspace and Rateable Value Statistics 1998-2004 (London: Office of the Deputy Prime Minister). Available at www.odpm.gov.uk/index.asp?id=1146088 (accessed 1 November 2007). 
ODPM (2005b) Commercial and Industrial Property Vacancy Statistics: England 2003/04 (London: Office of the Deputy Prime Minister). Available at www.odpm.gov.uk/index.asp?id=1146176 (accessed 1 November 2007).

ODPM (2005c) Previously-developed Land that may be Suitable for Development: England 2004; Results from the National Land Use Database of Previously-Developed Land (London: Office of the Deputy Prime Minister). Available at www.odpm.gov.uk/index.asp?id=1147697 (accessed 1 November 2007).

ODPM (2005d) Technical Report: Using Town Centre Statistics to Indicate the Broad Location of Retail Development-Initial Analysis (London: Office of the Deputy Prime Minister). Available at www.odpm.gov. uk/index.asp?id=1163774 (accessed 1 November 2007).

ODPM (2006a) Commercial and Industrial Floorspace and Rateable Value Statistics 2005 (2005 Revaluation) (London: Office of the Deputy Prime Minister). Available at www.odpm.gov.uk/index.asp?id=1163773 (accessed 1 November 2007).

ODPM (2006b) Technical Report: Development of Commercial and Industrial Property Vacancy Statsistics (London: Office of the Deputy Prime Minister). Available at www.odpm.gov.uk/index.asp?id=1164260 (accessed 1 November 2007).

O’Sullivan, D., \& Unwin, D. (2003) Geographic Information Analysis (Hoboken, NJ: Wiley). 